\title{
Defined Notification
}

National Cancer Institute

\section{Source}

National Cancer Institute. Defined Notification. NCI Thesaurus. Code C93411.

An administrative activity defined at the global library level that represents the communication of a message to a recipient. 